\title{
SYLVIUS AND THE REFORM OF ANATOMY
}

\author{
by \\ C. E. KELLETT
}

$T_{H E}$ first half of the sixteenth century in France is characterized by a rapid change in the ways of thinking and learning, and of the structure of society itself, by the emergence of a wealthy and educated middle class. The institutions of the planned medieval state survived but often with a curious change in balance. Philosophy became closely allied with Humanism and flourished not in the schools of the Faculty of Theology but amongst the colleges of the Junior Faculty of Arts. ${ }^{1}$ The most influential of its teachers, Le Fèvre, who played so important a part in the reformation, was a Master of Arts who began his studies in Theology but never became even a Bachelor in that Faculty. ${ }^{2}$ In the same way Sylvius, who was a pupil of Le Fèvre and also from Picardy, achieved his reformation of anatomical training within the colleges of the Junior Faculty and, though long after he had achieved fame as an Anatomist, he took his Doctorate at Montpellier, he never proceeded to the Licence of the Faculty in Paris, remaining a Bachelor. ${ }^{3}$

There are at present over 6o,00o students in the University of Paris, perhaps four times as many as there were then, for the Venetian Ambassador, Marino Cavalli, is quoted by Lefranc ${ }^{4}$ as reporting in 1546 that there were $16-20,000$ students, for the most part impoverished, in the University and that there was no lack of teachers who were, if anything poorer, or as Lefranc puts it, 'bien chetifs'. Many of these were studying for a higher degree in Law or Divinity but by a special act ${ }^{5}$ it was not possible to do this while taking the course for a degree in Medicine. As a result it was, as Sylvius ${ }^{6}$ pointed out on a subsequent occasion, difficult to become a Physician unless one had private means. For this he was taken to task by Henry Estienne ${ }^{7}$ in a characteristic passage:

But besides his intollerable covetousnesse, he had this bad qualitie, to envie the students of his profession, seeming to affect nothing more than to bring them to a dislike thereof. For proofe whereof I might here alleadge the oration which he made at his first and second lecture, when he was advanced to be the King's professor. But that I remember he would often say that a man could not be a Phisition without the knowledge of all arts and sciences, and that it was absolutely necessary he should be of a good and strong constitution. Yea that it was meere madness for poore schollers to studie Phisicke: alleadging for this purpose (besides sundry other arguments) the saying of Iuvenal: 'Haud temere emergunt, quorum virtuitibus obstat Res angusta domi.' It being requisite (and that for many reasons) that students in this art should have wherewith to maintaine themselves.

Sylvius was always poor. He was born in Picardy, the seventh in a family of fifteen. His father had been a weaver and, to the end of his days, he never 


\section{E. Kellett}

forgot the penury that had afflicted his earlier years. There were eleven boys; the third, François, became one of the founders of the Humanist renaissance in the University of Paris and eventually head of the College of Tournay but it was not until 1514 that he was able to bring two of his brothers to join him there. Jacques was the younger of these, he was already thirty-six years of age. During the next few years he helped his brother and from him learnt Latin; he mingled with his brother's friends and learnt Greek with Hermonymus of Sparta and Lascaris, Hebrew with Vatable and Mathematics with Le Fèvre, and gradually became a leading figure in that Humanistic movement so vividly described by Vives in his letter of i 521 to Erasmus. He too may well have joined in the boos, the catcalls and the uproar with which the Humanists greeted in the schools any proposition savouring of scholasticism and certainly he seems to have learnt their method of sonorous verbal abuse which replaced for them the subtleties of scholastic argument: He became interested in Galen, many of whose works were then beginning to appear in Paris in the fresh translations of Cop, Akakia, and Linacre, and just as his master, Le Fèvre, in his celebrated paraphrases endeavoured to make Aristotle clear and easily understood, so too he wished to summarize and clarify Galen's work. With his books for his guide he travelled into the fields to collect herbs throughout the Summer months and lived throughout the Winter months with the Barber Surgeons, in order to acquire a practical experience in Anatomy, a study which he pursued for the rest of his life. His fame spread as a teacher until students came from all over the world to listen to him, his audience being drawn from that great section of the University known as 'Les Galôches' a vast band of unruly students who roamed like Rabelais from University to University, taking a course here and there as they fancied. It was their good will alone and the small fees they paid that sustained Sylvius for so many years and enabled him to carry on his study of Anatomy until the last Winter of his long and arduous life. These fees too Estienne apparently begrudged him:

He was a man endued with most profound knowledge of Phisicke, and an admirable dexteritie in delivery of his mind, so that he could speake readily as good and pure Latin as his profession would permit: in a word, he was so rarely accomplished in regard of the Theorick, that if it had bin seconded by practice, he might well have bin reputed another Galen. But cursed covetousness had so possessed and poisoned his heart and had made him so forget God and all goodnesse that whereas (to manifest his gratitude to the giver of these gifts) he should have taught some poore schollers privately for the publick good: he contrariwise would not permit so much as five or sixe poore schollers to heare his publicke lecture gratis, not among two or three hundred who payed him monethly a quart d'escu a peece. Nay, it strooke him to the heart to see at his lecture (in the Colledge of Tricquet in Paris, where he used to reade before he was the King's Professor) two poore schollers who had payed him nothing, so that he commanded them forthwith to get them gone: which they being unwilling to do, he told the rest that except they thrust them forth, he would not proceed. Which I report not upon hearesay but as being an eye and eare-witnesse thereof.

But, despite this covetousness Estienne so deplored, he remained poor all his life and was at his own request buried in the poor students' graveyard in front of the College of Montaigu. The students, whom Estienne would have 


\section{Sylvius and the Reform of Anatomy}

us believe he so exploited, and indeed the whole University, the Doctors in their scarlet robes, followed him to his grave.

Renatus Moreau has compiled an excellent descriptive account of Sylvius, who was, he writes,

of short, square, stocky build. He was austere in his manner and rather intimidating but not without a certain refinement and affability. His voice was hoarse but of good volume and very moving; his beard thick and close cropped; his hair white and luxuriant, though he so disliked this profusion in anyone else that whenever he saw a beggar with his hair hanging down he made a bargain with him that he should go to a barber as well as the baker. He was exceedingly sharp witted and versatile; his memory capacious and singularly apt; his judgement felicitous. For the rest, he was notoriously prone to anger and vehement; but, in his private life, irreproachable, guilty of neither fraud, betrayal nor cruelty. Both in his written and spoken work he was so devoid of any uncouthness or solecism; so terse, so refined and so polished that he was held to be one of the finest orators of his period; an accomplished poet, a most finished grammarian, an eloquent physician and profound mathematician. His constitution was excellent and his health was good.

Twelve years after he had dined with them in Paris, when both Sylvius and Fernel had been dead many years, Cardan, ${ }^{8}$ lonely and unhappy in Bologna, added to his De libris propriis a further section which dealt in the main with his present grief and the memory of happier times when he crossed Europe on his way to Scotland. He recalls. Fernel, tall, thin, but a few years his senior and Sylvius, in his seventies, short, cheerful and full of fun; his hair snow white.

Many of the students at that time were of uncertain age and not very interested in the pursuit of knowledge; they learnt fencing from unemployed soldiers, frequented the brothels and inns, they waylaid the citizens and robbed them of their money. They despoiled the vineyards and fought with the townspeople. They became such a nuisance that the Parliament of Paris in August $1554^{9}$ passed a series of laws forbidding anyone to give shelter to a student. They were to wear sober clothing and avoid hats with such brims that their faces were concealed. Proctors and M.A.'s were to attend University meetings properly gowned in order that the students might recognize them and pay them the respect they were due. Fencing and swordplay was to be regularized, taverns closed to students after dusk and ladies of easy virtue removed.

Noel du Fail ${ }^{10}$ would have appeared to have been just such a student and one of our most reliable authorities on this period. The son of a small Breton landowner, he was born about $\mathrm{I} 520$ and came to Paris under the care of a friend of the family, Colin Briand, who was earning by his lectures the wherewithall to pay for his course in Law. There he led what one of his editors terms the ordinary life of a student,

a strange mixture of work, of dissipation and of debauch. It is [writes Philipot] ${ }^{11}$ remarkable that the only teacher in Paris that he should mention in any detail or describe should be a Professor of Medicine who was very modern in outlook, who, moreover, practised experimental methods.

This physician-philologue was Jacques Sylvius. 


\section{E. Kellett}

I remember [he writes] ${ }^{12}$ listening to that fluent Latinist, Jacques Sylvius, reading Galen's De Usu Partium at the College of Tregierre in Paris before a marvellous audience of scholars of all nations. But when he came to the description of those parts we call shameful, there was no corner or place which he did not name in good French both by name and surname, adjusting the diagrams and figures accordingly for the more ample demonstration of his lesson, which had been altogether without taste nor flavour had he evaded the issue and done otherwise. I have seen him bring tucked up his sleeve, for all his life he lived without a servant, at one time the womb of a goat or lamb, and all the pelvis, at another time the thigh or arm of a gallowbird, to dissect and anatomize, that had so foul a smell, so powerful a stink, that several of his auditors had readily vomited had they dared but the old scoundrel with his hot Picard blood (le paillard avec sa teste de Picard) flew into such a temper, threatening not to return for another eight days, that all resumed their former silence.

It is probable that in that vast audience there was not one who proposed to practise Medicine but among the four or five young men who helped him with the anatomical preparations, the diagrams and the figures (les figures et pourtraits) were at about this time three young men, Vesalius, Vassé and Charles Estienne. The information Vassé ${ }^{13}$ gives us enables us to understand more clearly the nature of Sylvius' influence over his unruly audience. This depended not so much on his splendid use of the Latin tongue as upon the exceptional clarity of his thought. He was, moreover, never tired of teaching and so taught that none of his students ever tired of learning. He had an astonishing power of enabling them to grasp and see quite clearly that which a moment before had seemed impenetrable and terribly involved. His success gave rise to jealousy but in $153^{2}$ he made his peace with the Faculté. He had gone to Montpellier, where Rondelet was his friend. He had been accepted and allowed to matriculate in November 1527 , within a week or so of his arrival and was accepted as a Bachelor in 1529. In the following year he apparently took his Doctorate. He, moreover, had printed by Robert Estienne in handsome style his Introduction to French Grammar ${ }^{14}$ - the first French Grammar ever to be written-which he dedicated in January I53 I to Queen Eleanor. Such a book was calculated to please the young woman, the sister of Charles $V$, who had that very year come to the Court of France and knew little French. It could scarcely offend the Faculté, who could, however, have prohibited a book on a medical subject. They would be quick too to take a hint from the Court.

The Faculty of Medicine was probably by far the smallest of the three senior faculties and the most difficult of entry. All who were accepted and qualified were admitted as Members without distinction and from their numbers were elected the two whose duty it was to teach the candidates for admission, and the Dean. In 1395 there were thirty-one members; in 1500 there were seventytwo; in 1568 there were eighty-one and in 1626 there were eighty-five. As in the guilds their numbers were related to the amount of business available and preference was given to the sons of former Members. Somewhere in the region of half a dozen candidates were chosen every two years. The majority of these had already taken the degree of Master of Arts and were, therefore, excused twelve months of further study. Even so they were required to devote the whole of the next thirty-six months to study within the Faculty before sitting for their 


\section{Sylvius and the Reform of Anatomy}

degree of Bachelor of Medicine. During this time they were not allowed as we have seen either to attend or give lectures in the Faculty of Arts. The next two years were spent qualifying for the Licence to practise and teach-during this time they attended a variety of practical courses and even, it would seem, dissected. But once they had passed their examination for the Licence, had been presented by the Beadles ${ }^{15}$ of the Faculty to the notables of the City, had invited them to the Signeta and had the Licence granted them in ceremony by the Chancellor of Notre Dame, then they promised solemnly to adhere to the statutes of the College, including that which forbade them indulging in the practice of Surgery or Anatomy, or any manual craft-for the dignity of the profession was dependent on this ban. Though it seems as if Sylvius had hoped he might be granted the Licence, it is probable that he was well satisfied with being admitted to the grade of Bachelor and glad when, on the 27 January 1536, his position as an extra-mural lecturer was recognized by the Faculty, for, by remaining a Bachelor, he had retained his freedom to dissect. The rather perfunctory demonstration carried out before a small audience by a Barber Surgeon, under the direction of a Physician, whose text was Mundino's, could scarcely have appealed to him. These were, as shown in the frontispiece of the French version of Mundino, frequently carried out in one of the small enclosed gardens which were a feature of the city at that time and, indeed, so long as they were based on this text and so corresponded very closely to the routine hospital autopsy, it is probable that clandestine dissections took place far more frequently. Ambrose Paré ${ }^{16}$ was probably not exaggerating when he claimed that during his three years as a resident at the Hôtel de Dieu de Paris he had had the opportunity of learning on an infinity of dead bodies all that can be said or dreamed of in Anatomy.

The change to an anatomy involving dissection of the muscles, nerves and vessels, as opposed to the simple demonstration of the organs of the three cavities of the body, owed much, however, to a Member of the Faculty, a close friend of Sylvius, Winter of Andernach (1487-1574) who had been Professor of Greek at Louvain before coming to Paris in 1525. He was one of the few fluent Greek scholars of his time. Lascaris and Budé were his friends and the Cardinal du Bellay one of his patrons. He found refuge in the house of Jean Tagault, a distinguished member of the Faculty, who appeared to have welcomed him in their midst. He was admitted a Bachelor in 1528 and a Doctor of Medicine in 1530; while five years later the King, Francis I, appointed him as one of his Physicians. During these years he had published, with Simon de Colines, a number of translations of Galen into Latin, which revolutionized the outlook of the Faculty. These included in I53I his translation of Galen's nine books of anatomical procedures, which were thus, after an interval of little over a thousand years, made available again to the learned world. In 1536 he wrote the text of an anatomy designed it would seem to take the place of Mundino's practical manual, which had been used for so many years. This had been based on Galen's work at second hand and Andernach's version was based upon the newly acquired original text. 'There is nothing in it', he wrote, 'which has not 


\section{E. Kellett}

been written by Galen and nothing described which $I$ have not confirmed with my own eyes,' and if at times he was too ready to see certain small structures not really there, this is a fault common to all students. The book is terse and beautifully written and very much to the point. It indulges in no tedious teleological surmise and this is in striking contrast to Mundino's text. It has, moreover, a special section devoted to the dissection of the limbs. A dissection which for a time became the hall-mark of an anatomist of the New School, who was not infrequently portrayed, as in the well known woodcut of Vesalius, with such a dissection by his side. ${ }^{17}$

Andernach had neither the skill nor, we may assume, the desire to carry out the dissections involved, which were moreover forbidden him by his oath and they were accordingly done under his instructions by two young men, whose names he has himself preserved in the edition of 1539 . They were, as is well known, Vesalius and Servetus, both of whom also were attending lectures by Sylvius. It is probable, however, as $\mathrm{O}^{\prime} \mathrm{Malley}^{18}$ points out, that they succeeded one another rather than worked together as assistants to Andernach.

Sylvius had not sufficient knowledge of Greek to undertake the work Andernach had done; there were very few in Paris who had. But he was a skilled anatomist, which Andernach was not. Andernach's beautiful books were generally introduced by a preface addressed to the great Princes of the Church and State, the du Bellays, who had assisted him, but one, his version of Leoniceno's translation of Galen's De Musculorum was addressed appropriately enough to his dear friend, Sylvius. This was in 1528 , three years before Sylvius had published his first book and when he was still unpopular with the Faculty and so the more generous a gesture. He was now free to publish his own medical works, without running the risk of having them confiscated. His first book on French Grammar was not unrelated to this. The synoptic charts which played so important a part in his teaching had already been used by Le Fèvre d'Estaples in order to teach the little Madeleine of France her grammar. This was summarized in twelve tables, which were to be pinned to the wall of her room so that she might always have them before her eyes and be able to see at a glance one particular aspect of the language. In 1529 they were published in a modified book form by Simon de Colines, who tells us in the Introduction how they came into being and were meant to be used. In I 535 he printed for Sylvius, at the request of his students, the six great charts in which he showed how clearly the signs and symptoms of disease and their causes could be related to the doctrine of the four elements, the humours and the distempers. Only one set of these fugitive sheets has survived but in 1539 they were published by Wechel in a folio book. ${ }^{19}$ Each table was so re-arranged that it fits on four or five pages. During the next two years. Sylvius published with the same printer Linacre's version of Galen's work on the Temperaments and on the Faculties, in which again in the Introduction this tabular form is used with great success. On the other hand he seems to have felt Galen's De Usu Partium unsuited for this sort of treatment but, by means of an extensive index, he hoped to make the edition he published in $\mathbf{1 5 3 8}$, with the help of Martin Gregory, of use to the ordinary 


\section{Sylvius and the Reform of Anatomy}

student. He never completed his Commentary on this book and we shall, therefore, never really know what tables, what figures and diagrams he used so to intrigue Noel du Fail. Since the time of de Mondeville, anatomical pictures had been freely used for teaching and it is reasonable to suppose that we may detect traces of these diagrams in certain of the illustrations used by Charles Estienne and in the Vesalian Tabulae Sex. It is perhaps strange that he should have ever severed his connexion with the Estiennes and changed his publishers, moving as did Fernel from de Colines to Christian Wechel. It may be he distrusted Charles Estienne, Colines' son-in-law, who had recently returned with De Baif from the Embassy in Venice and was now actively. engaged in the Press and producing a number of little works designed for popular consumption, which must at times have seemed to bear too close a relation to the rather less readable books leaving the family press. Certain of these, the three little books based on his patron De Baif's three monographs, the De Re Vestiaria, De Vasculis and De Re Navali, were quite openly published as selections designed especially for schoolboys and, indeed, each had been re-arranged and most skilfully re-written for the purpose. On the other hand there must have been some who felt that his even more successful series. on husbandry-the De Re Hortensi, Seminarium, Vinetum, Arbustum; Sylva and Pratum -owed as great if unacknowledged a debt to Ruelles' great work De Natura Stirpium, at that time passing through the Press of his step-father.

A few years later Estienne de la Riviere, then a relatively unknown Barber Surgeon but destined to rise to the head of his profession, accused him publicly of endeavouring to appropriate as his own a book confided to him for translation and publication. As is well known, the matter went before the courts and finally a small commission was appointed to help decide the issue. This is not the moment to dwell on this book, the unfortunate De Dissectione Corporis. Its relation to De Anatomicis Administrationibus published by de Colines in I53I emerges from its rather more felicitous title and once again one has the feeling of encountering in the main that excellent summary of other people's work enlivened here and there by a personal note, which is such a feature of Charles Estienne's publications.

Loys Vassé of Chalons sur Maine was apparently entrusted by Sylvius : with preparing in tabular form a summary of Galen's views on the anatomy of the human body. He was one of his personal pupils and may have deputized at times for him, for Estienne mentions being present at a dissection carried out by him in which the subject was found to have a 'horse shoe' kidney.

His book In Anatomen corporis Tabulae quatuor was published by a small syndicate of printers in Paris in I540. The first issue was by Gautherot, the second by Fouscher and the third in the following year by Faezandat. Within a few months of its appearance, it was translated by Jehan Canappé into French and published by Dolet at Lyons in 1542. Latin versions were printed abroad and the book proved so popular with medical students that two editions were published in Venice in 1544 and ${ }_{1549}$, presumably to meet the demand in Padua. As we have seen, the book begins with a glowing tribute to Sylvius: 


\section{E. Kellett}

He does justice to his fame as a teacher and acknowledges his indebtedness to him. He deplores those who, having learnt all they know from him, belittle and besmirch him, and probably refers here to Charles Estienne rather than to Vesalius.

Galen's views on the anatomy and functions of the various organs and parts of the body are neatly summarized. They are derived in the main from the De Usu Partium and the De Anatomicis Administrationibus. References are given, and the Greek, and, on occasion, the Arabic equivalents of names. The lack of an adequate nomenclature is, however, evident, particularly in those sections dealing with the muscles of the body and limbs.

The book succeeds admirably in giving a clear and concise account of a complex subject. It represents Sylvius' own teaching and makes use of his methods of exposition. His own Isagoge or Introduction to the Anatomy and Physiology of Galen has at first sight much in common with it. Though the general arrangement is different, here too are tables superficially very alike.

This-The Introduction to the Anatomy and Physiology of Galen-was published by John Hulpeau in 1555 as a small folio. Sylvius had been working on the book on and off for most of his life and it was unfinished at the time of his death. The privilege or copyright for a Latin and French version, which was published the same year by the same publisher but in sixteenmo, was granted to his brother John Sylvius. A pirated edition of the Latin version was published in Basle the following year.

This book was designed, not as a summary of The Anatomy of Galen and Hippocrates, but as an introduction to that anatomy based on the modern approach to the subject he had in a sense initiated. This involved in the first place accounting for certain small differences in the old and new anatomies and reconciling them. It had soon become apparent to him that no two subjects were exactly alike; quite significant variations might occur, particularly in the venous system. At times it seemed as if these variations were related to differences in their general build. This in turn was, as Hippocrates had pointed out many years ago, influenced by climate. There was the further possibility that changes might have occurred in the anatomy of man in the course of time, and reason for believing that this might be so. It was generally felt that people had lived longer in the past. Gross variations were present between various domestic breeds of animals, such as sheep or dogs. His Preface to the reader, which he seems to have left in a finished form, is too often dismissed as a rather feeble attempt to excuse Galen's so-called mistakes.

The problems with which he was concerned are still in need of solution and have been in the main glossed over.

The medical student [writes Lubosch] ${ }^{20}$ must therefore all the more regard it as his task to interpret without prejudice every individual relationship presented to him in the cadaver and museum preparations; indeed, he will be wise to seek diligently for individual variations from the descriptions in his textbook and atlas.

Though time has dealt rather harshly with some of the authorities Sylvius quotes, his Preface, in striking contrast to all the other introductions of that 108 


\section{Sylvius and the Reform of Anatomy}

period, has something in common with the Oulines of Scientific Anatomy designed by Lubosch as an introduction to supplement usual textbook teaching.

The Isagoge proper or Introduction to the anatomical part of the physiology of Hippocrates and Galen is divided into three short books, each with its own brief proem or preamble. In the first of these he deals briefly with man and the outer world; with matter and form; with the four elements, fire, air, water and earth; and with the four humours, the stuff of which man is made. He refers his readers to the great classical authors, Aristotle, Hippocrates and Galen, and deplores, perhaps too violently, the intemperance of their modern critics.

The book proper is devoted to the study of the various tissues encountered on dissection, whose descriptions are scattered throughout the works of Galen. As he proceeds from the study of bone, cartilage and ligament, to that of membrane, fibre or smooth muscle, flesh or muscle proper, we become very conscious of how much modern histology owes to the microscope. Nevertheless there is much here of value, and, in the section on membranes, a paragraph of importance to the history of anatomy.

The presence of the ductus arteriosus and the foramen ovale was known to Galen.

Nature [he wrote in a characteristic passage] is neither lazy nor devoid of foresight. Having given the matter thought, she knew in advance that the lung of the foetus, a lung still contained in the uterus and in the process of formation and spared continual motion, does not require the same arrangements as a perfected lung endowed with movement. She has, therefore, anastomosed the strong, thick and dense vessel with the large artery and the thin, feeble and porous vessel with the vena cava. ${ }^{21}$

Here, were it not for Galen's emphasis on function and teleology, it would be almost impossible to follow him. Elsewhere, however, he describes both the ductus arteriosus and the foramen ovale in greater detail. Sylvius in the following passage on the foramen ovale and its valve-like fold adds to his description and by means of suitable names avoids much that is rather clumsy and uncertain in Galen's description. If we are to understand him, however, we must bear in mind that Renaissance anatomists still considered the right and left auricles as part of the vena cava and pulmonary veins respectively.

There is [he writes] a certain membrane in the short vessel connecting in the foetus the vena cava with the pulmonary vein whose appearance is rather like that of a little lid. This is easily deflected towards the pulmonary artery, ... and thereby the blood of the vena cava is prevented from flowing into the lungs. This membranous protrusion is thickened and grows together, sometimes on the first day after birth, sometimes after several days, when at length its whole body hangs down in such a way into the cavity of the vessel that it completely occludes it and it cannot be split asunder. There is also a similar projection of membrane at the mouth of the vena azygos and often at those of several other large vessels, such as the jugulars, brachial and crural veins and the trunk of the vena cava as it leaves the liver. The use of these is the same as that of the membranes closing the mouths of the vessels of the heart.

We have here a clear indication of the valves present in the veins and the difference between his description and that of Fabricius, Harvey's teacher, is 


\section{E. Kellett}

largely occasioned by the excellent illustrations in Fabricius' Monograph. Sylvius' contemptuous dismissal of illustrations in Anatomy was in part due to his humanist outlook and to the quality of those he was familiar with. Illustrated books were felt to be a gothic survival. When, as in the case of the Strasbourg School, they were used to illustrate a classic text such as that of Virgil, they excited the derision of the learned. The illustrations Berengario had added to his edition of Mundino were in many respects even worse, for they were a makeshift haphazard collection. They were, as Sylvius once said, a Hodge Podge, sumptuous perhaps but of no real value to the student.

Sylvius was curiously afraid of anything, be it an image or even a name, which might become a substitute for the real thing. On the other hand names fascinated him. The Preamble to the second book, which embodies his great contribution to anatomy, begins therefore almost with an apology.

We have [he writes] amused ourselves with coining new names for certain parts of the body, especially the veins, arteries, nerves and muscles. In this we have taken Hippocrates and Galen as our models and have aimed at achieving conciseness and at the same time clarity in definition.

He deals at length and for the first time with the principles underlying anatomical nomenclature.

It is [he points out] really a sort of game, the rules for which can be deduced from the earlier writers. Parts may be named after their appearance or after their position or function. The whole object of the exercise was to find a name that would enable one readily to identify a structure and its function.

Sylvius would seem to be a little apologetic for the pleasure he had derived from this. The extent of his contribution can perhaps be most readily determined from a study of Singer's recent translation of Galen's text. ${ }^{22}$ There, whenever the name of a muscle is missing, its modern name is inserted in brackets. It is remarkable how often such an insertion has to be made and, if we compare the modern name with that used by Sylvius, equally remarkable how often one either corresponds with or has been derived from the other.

This is the most important of the three books that constitute Sylvius' introduction to the anatomical works of Hippocrates and Galen. Some competent to judge believe it to be also one of the most important in the history of anatomy. This, writes William Cowper, ${ }^{23}$ is

that incomparable piece entituled Isagoge Anatomica, wherein he digested the muscles and vessels into order, which were treated of confusedly before by Galen, Vesalius, Columbus and Fallopius, and distinguished them by those Names that are still in use.

Yet it is characteristic of Sylvius and his essential modesty that he should have had misgivings and in the final paragraph of the Isagoge recalled

how Galen had often wished it were possible to teach a thing without the use of names, for the names themselves are but the shadow of reality.... . 


\section{Sylvius and the Reform of Anatomy}

In the proem to the final book dealing with splanchnology, Sylvius states that he will compress what he has to say into the fewest possible words compatible with clarity. As for the functions of each part and their utility, once again as in the two previous books, he refers his readers to the books of the De Usu Partium, lest, he adds,

we, whose feathers are so dull, deck ourselves out with the feathers of Galen after the fashion of any one of these carrion crows of Aesop, who nowadays infest us.

The third book covers much the same ground as did Mundino and so serves to emphasize the difference between the new anatomy, which was based on the De Usu Partium and the newly translated De Anatomicis Administrationibus of Galen and the old based on Mundino and Berengario da Carpi. Mundino, as he proceeds, indicates the next step to be taken by the Ostensor and much of what he has to say is only indirectly related to the part or organ displayed. Having finished with the organs in the three cavities of the body, he has the body divided lengthwise into two parts, beginning from the neck and going even to the tail. This procedure, still common enough in a slaughter-yard, was followed by the removal of the skin from the arms and legs, enabling the larger superficial veins to be studied but beyond that he did not go.

Below the veins thou wilt note [he wrote] many muscles and cords great and thick, but do not trouble to search out their complete anatomy in such a body. Use rather a body dried in the sun for three years. ${ }^{24}$

Sylvius on the other hand gives no instructions on the display of the parts he describes but devotes his last chapter to the management of an anatomy.

This [he writes] for me consists in the choice of the body, of suitable instruments, and in the modes of incision.

$\mathrm{He}$ is not concerned with the setting of the anatomy, with the building and with the arrangements to be made to deal with the onlookers, as was Benedetti ${ }^{25}$ and, it would seem rather optimistically, Charles Estienne, nor is there here any question of dissectors working under the instruction of the physician, such as Estienne envisaged. His first concern is with the choice of a body. It was preferable that it should be that of a young adult male and well proportioned and Lubosch reminds us how exceptional under modern circumstances such a subject would be. On the other hand, this was not essential and the very fat and the very thin, as well as the young and the old all have, from the point of view of the dissector, certain virtues of their own which he enumerates. Nor, Sylvius adds, should one only dissect human subjects but also the bodies of monkeys and of other animals which have much in common with man. In his view, it is preferable, to begin with, to dissect the human subject only, and, once one has mastered his anatomy, compare it with that of other animals. This, despite the contrary practice amongst the ancients, who first mastered that of the monkey, either because there were more of them than of men available for dissection, or else, because by so doing they gradually became inured to the 


\section{E. Kellett}

idea of dissecting the human body. For there are, he adds, students who may faint at the mention of a disease and many more who faint at the sight of a wound or of blood. Most people indeed are averse to human dissections and to begin with tolerate the sight with difficulty, and yet he urges them from the beginning to view a dissection on a human subject and then to confine their dissections to man. It is by far the quickest and surest way to learn and prevent the confusion that even at his time existed between the anatomy of man and the monkey.

Sylvius then mentions that Galen used to drown his monkeys before dissecting them and points out that from the point of view of the anatomist this is preferable to having a subject who has been killed by strangulation or beheading, or who has died as a result of wounds or some disease. He dwells briefly on the instruments one should use and then gives this very practical advice on the dissection of the blood vessels. He assumes throughout that the anatomist will himself carry out the dissection.

Thus [he writes] if you wish to investigate the arteries and veins, dissect them out with your finger nail or a blunt knife and a gentle hand, lest you should rupture their wall and so flood your work with a confusing mass of blood, so that you may see in what directions and how many branches they are distributed. Should you, however, lack faith in your skill, counter this by ligaturing them at frequent intervals with a cord passed round by means of a bookbinder's needle and tied, so that if you are imprudent and sever or cut the vein, only that small part between the ligatures will bleed. Alternatively in the event of a large effusion of blood confusing the whole field of your operation, pour it off and wash the tissues down with water. Then you may finish off the dissection you began by threading into the vessels thin wires, either of iron or lead, or even of plant fibre and, following the wires, be able to dissect out all the vessels and their branches. You can, moreover, make use of a happy device for exploring the distribution of the vessels, inflating them through tubes, which I prefer to injecting them with a fluid dyed either yellow or any other colour, since in the latter method the dissection is disturbed should the fluid pour out, whereas by the other the veins are rendered the more conspicuous because they are distended.

Here perhaps we should stop for from here to Fabricius of Aquapendente and from him to William Harvey there would seem to be but a single step.

\section{ACKNO WLEDGMENTS}

I am glad to have this opportunity of thanking the Librarians of the Faculties of Medicine of Paris and Montpellier for their assistance and in particular Mademoiselle Paule Dumaitre and Mademoiselle Y. Vidal for the references to Sylvius in the records of the two Faculties. Mademoiselle $Y$. Vidal was, furthermore, kind enough to make sure that there was no evidence of Rabelais and Sylvius having made the journey from Paris to Montpellier together as I had at one time thought possible, and that it is indeed likely that they never met at Montpellier, the last entry bearing the name of Sylvius occurring in November 1529, whereas Rabelais matriculated on the $17^{\text {th }}$ September $153^{\circ}$, and was admitted as a Bachelor in November $153^{\circ}$, taking the Doctorate on the 23rd May 1537. I find it difficult to account for the different treatment Sylvius received and yet there seems to be no doubt but that the first entry is on page 95 on the register under the year 1527 and the second on page 106.

I am glad too to have this opportunity of thanking Dr. Poynter of the Wellcome Historical 


\section{Sylvius and the Reform of Anatomy}

Medical Library for his kindness in letting me have a microfilm of the Tabulae Quatuor of Vassé, as well as of certain prefaces of Winter of Andernach. I also thankfully acknowledge my debt to the late Dr. Charles Singer, without whose encouragement this little paper, which has been several years in the making, would never have been brought to a conclusion.

\section{NOTES AND REFERENCES}

I.

Hos superat tamen, vicinus Cinthius ignes, Sylvius, aetatis gloria certa suae.

Argiuo solita est gaudere Machaone quondam, Helladis in Phrygias ora profecta domos.

Thessala Phyllirio tellus Chirone tumebat, Cum patriis legeret pharmaca nata iugis. Doctus Francigenas extollit Sylvius oras, Iure sua tantum Gallia prole tumet.

Lutetiae Parisiorum Descriptio autore Eustatio a Knobeldorf Pruteno. Christian Wechel, 1543. Reprinted Paris 1611, p. 203.

Sylvius is the only Member of the Faculty of Medicine mentioned by Knobelsdorf, who was a student in Paris for about sixteen months (1541-43) - see Lefranc, A., La vie quotidienne au Temps de la Renaissance, Paris 1947, p. 180. He makes special mention of the College de France and devotes several lines to Galland, Toussaint, Strazel, Vatable, Paradis and Vidus Vidius, and his inclusion of Sylvius and the amount of space he devotes to him does suggest that the students felt he too should have been appointed.

2. Renaudet, Augustin. Prérforme et Humanisme d Paris. Paris 1953, p. 130 et passim. Gives an excellent account of the complex factors at work giving rise to the Reformation in France and of Le Fèvre d'Etaples, who so influenced Sylvius and thus indirectly the study of anatomy.

3. Renatus Moreau, who published a collected edition of the works of Sylvius in 1630 , prefaced it with an excellent account of his life. This was apparently to be one of a series of lives of distinguished members of the Faculty of Medicine of Paris and Astruc is probably right in suggesting that Moreau deliberately omitted the words 'Doctor of Montpellier' from the passage in the Register of the Faculty of Paris, which he quotes. Having done this he asserted that Sylvius went to Montpellier to take a degree but felt it beneath his dignity to join such a Faculty. Bayle, who is more readily accessible and, therefore, more widely read, suggests that he returned without a degree because he was too mean to pay the fees. Both suggestions throw more light on their authors than on Sylvius, who undoubtedly went to Montpellier, duly matriculated and paid his fees, and presumably, since he is officially designated as such, ultimately proceeded to the doctorate. Astruc's account is, therefore, in the main correct but many of his dates seem at fault. I am told that there are two entries in the Register at Montpellier, the first in 1527 and the second in November 1529 , so that no special exception was made in his instance and two years had elapsed between his matriculation and the award of his degree of Bachelor. These two entries, which are apparently in his own handwriting, are reproduced, together with the two references to Sylvius in the Commentaries of the Faculty of Paris, the dates of which again differ slightly from those generally accepted, e.g. Thuasne, L., Villon et Rabelais, Paris 1911, pp. 329.

Notes sur Jacques Dubois (Sylvius) extraites des Commentaires de la Faculté de Médecine de Paris, tome Iv, $1511-32$.

Fol. 301 28a junii 1532, convocata est facultas apud scolas super tribus articulis deliberatura per juramentum. Primus concernit supplicationem docti 


\section{E. Kellett}

Jacobi viri magistri Jacobi Sylvii. Secundus publica negocia facultatis. Tertius Sylvii supplicationibus et injuriis est accomodus. Quantum est primi, supplicuit supplicatio predictus magister Jacobus Silvius pro probatione temporis studii requisiti ad ad examen baccalaureat et post adeptionem gradus baccalariatus, requirebat facultatem admitti ad respondendum post aliquos menses de questione cardinali et et hujus iterum de questione quolibetaria, si opus esset, subinde admitti ad licentias. favor in Audita supplicatione et eleganti oratione ejus, placuit facultati admittere eum predictum Sylvium ad examen et gradum baccalariatus, probatis probandis et solutis solvendis. De reliquis facultas videbit posthac de agendis tamen cum gratia et favore propter literaturam ejus.

Fol. 309 Recepi a magistro Jacobo Sylvio qui probavit sex annos finitos in festo Omnium Santorum 1529 sex schedulis non registratis, et sic debet sex schedulas et sex emendas valentes. . .xx. 1. Xv. s.t. (IX livres, $x v$ sous tournois).

Notes sur Jacques Dubois (Sylvius) extraites des Commentaires de la Faculté de Médecine de Paris, tome v, I532-44.

Fol. 62 XXVIIa januarii (1536) .... item statutum est ... praeterea quod qui medicinam extra scholas medicinae profitebantur possent deinceps legere in scholis et mercedem suorum laborum ibidem ut et alibi a scholasticis accipere. Hoc autem statutum est propter . . . Jacobum Sylvium bacchalaureum scholae Parisiensis et doctorem Montispessulani, qui medicinam profitebatur in collegio Tricquet.

4. Lefranc, A be L. Histoire du College de France. Paris, 1893, p. 165, passim.

The idea of a college in which the teachers would receive a salary from the King and be relieved of some of their dependence on their students' fees and on the goodwill of the senior faculties, plays an important role throughout the whole of this period. The first appointments were made in 1530 . It was known that the King had in mind an appointment in Medicine and reason for believing that Sylvius would have welcomed it, and probable that Charles Estienne hoped he might be awarded it. The appointment was not, however, made until 1542, being given to Vidus Vidius, who held the chair until 1547, when it was offered to Sylvius, who, after some hesitation, accepted it and held it from 1550 to 1555 , the year of his death.

See too. Kelnett, C. E. Histoire de la Médecine, 1956, pp. 17-27. Le Cardinal Wolsey et l'Abbaye de Theleme.

5. Wickershermer, E. Commentaires de la Faculte de Médecine de l'Universite de Paris, (1395-1516), 1915. Preface et Introduction-p. 19.

This contains a great deal of valuable information on the way Medicine was learnt and taught in the Faculty during this period, as do several works of A. Franklin, more especially La Vie Privee D'Autrefois-Les Medecins, Paris 1892 and Les Chirurgiens, Paris i893.

6. Syivius, J. Ordo et ordinis ratio in Legendis Hippocratis et Galeni Libris. Paris, 1541, p. 5. In this book Sylvius gives a good account of a medical curriculum based in the main on these two authors, though he mentions many of his contemporaries. It gives him an opportunity of voicing his dislike of illustration as being inadequate and of emphasizing the need of repeatedly handling the parts of the body as well as seeing them. The Introduction addressed to Lyset, the President of the Parliament of Paris, consists in the main of an eloquent defence of that regular order without which development cannot take place.

7. Estienne, Henri. Apologie pour Herodote. The quotations are taken from the English translation, $A$ World of Wonders, Edinburgh, 1608, p. $121-2$.

The translation is fairly accurate but $I$ doubt whether un quart d'escus is correct for the 'teston' in the original. 


\section{Sylvius and the Reform of Anatomy}

8. Cardan, J. Somniorum Synesiorum, etc., to which was added De Libris Propriis. Basle, 1585, p. 91

9. Pö̈ te, Marcel. Une Vie de Cite Paris. Paris 1931, III, 35, et passim.

The first two chapters of this volume (5I and 52 ) deal at considerable length with life in the Latin quarter during the period with which we are concerned.

io. Fail, Noex du. Propos Rustiques, etc., Ed. L-R Le Fevre. Paris 1928.

11. Philipot, E. La Vie et l'oeuvre litteraire de Noel du Fail. Paris, 1914, p. 67.

12. F AIL, NOE L DU. Les contes et discours d'Eutrapel. Rennes, 1597, p. 114 .

13. VAsse, Louis. In Anatomen corporis humani Tabulae quatuor. Paris, 1540. Preface.

14. Armstrong, Elizabeth. Robert Estienne, Royal Printer. Cambridge, 1954.

This book, which gives valuable information on the condition of the book trade in Paris at this time and of the powers possessed by the higher Faculties of censorship, describes this work at length on p. 107. Sylvius was, however, very far from 'becoming the most prosperous and fashionable Paris doctor of the time' as this author suggests.

15. Goulet, Roвert. Compendium on the Magnificence, Dignity and Excellence of the Univerersity of Paris in the Year of Grace 1517. Translated by BUR Ke, R. B. London and Philadelphia, 1928, p. 89-91.

Goulet gives a detailed account of the ceremonies associated with the granting of the Licence and of the Ceremony of the Signeta which immediately precedes it.

16. Oeuvres Completes D'Ambroise Paré. Ed. Malgaigne, J. F. Paris, 1840, 3 vols., I, ccxxxii.

I know of no figures available to cover the actual years Paré was at the Hotel Dieu but the deaths for the three years were probably little short of ten thousand and discipline was notoriously lax.

Coyecque, L'Hotel-Dieu de Paris au Moyen Age. 2 vols. Paris, 1891. 1, 119, gives the following figures for the decade or so earlier.
15222,471
$1523 \quad 3,766$
$1524 \quad 5,729$
15252,097

17. For a discussion on this point see Heckscher, William S. Rembrandt's Anatomy of Dr. Nicholas Tulp, New York, 1958, p. 73, and also The Burlington Magazine, April 1959, p. 152.

18. Michael Servetus. C. D. O'Malley, Philadelphia, 1953, p. 55.

19. Methodus Sex Librorum Galeni in Differentiis et causis Morborum et symptomatum in tabellas sex ordine suo coniecta paulo fusius, ne brevitas obscura lectorem remoretur \& fallat. Paris, Christian Wechel, I539.

In 1538 Leonhardt Fuchs prepared a similar sheet, of which again only one copy seems to have survived, The Tabula Oculorum Morbos comprehendens-a facsimile of which was issued in Palo Alto, California, 1949, with an Introduction by Professor O'Malley.

20. Luвоsch, W. Outlines of Scientific Anatomy. Translated by Woollard, H. H., London, 1928, p. 134.

21. Gale n. De Usu Partium. Ed. Sylvius. Wechel, 1538. p. 184, lines 25 and 26.

'alterum quidem vas validum crassum ac densum ad arteriam magnam: imbecillum vero an tenue ac rarum alterum ad venam cavam anastomosi adplicuit'.

See too:

Gale n, Oeuvres, Anatomiques, Physiologiques et Médicales, translated by Darember G, C. Paris, 1854. I, 452, where Daremberg names the vessels and expresses the view that Galen must here be referring to the Ductus Arteriosus and the Foramen of Botal, and again $\mathrm{XI}, 148$.

Senac, M. De. Traité de la Structure du Coeur. 2nd ed. Paris, 1777. Lib. 2. Chap. 2, discusses the history of this foramen at length and gives two further references to Galen, both again in his De Usu Partium. He points out that not only was Botal ignorant of former work but that the description he gives is confusing rather than illuminating. It is, nevertheless, remarkable that Senac, so learned and so fair, should be unaware of Sylvius' description. 


\section{E. Kellett}

Willis, R., in his William Harvey, A history of the circulation of the blood, London, 1878, p. 53, reproduces this passage which at the end contains the first reference to valves in the veins. It is disconcerting to find in a delightful book, which seems so accurate, Sylvius described as 'the scion of a family in easy circumstances' who had 'enjoyed the advantages of a liberal education without having to struggle for it'. Sad once again to be told he was 'a miser in the most absolute sense of the word. He lived a solitary life as a bachelor, scarcely allowing himself the barest necessaries of life and no fire throughout the bitter Parisian winter; but would take a turn at hand-ball ever and anon in his chamber to keep himself warm.'

22. Galen on Anatomical Procedures. Translation with Introduction and notes by SINGER, Charles. Oxford University Press, 1956.

And some of the names are listed by $\mathbf{E}$. Wickersheimer, La Médecine et les Médecins en France a l'epoque de la Renaissance. Paris, 1906, p. 237.

23. Myotomia Reformata. By the late Mr. Cowper, Wilciam. London I 724, in the Preface.

24. The Fasciculo di Medicina. Venice, 1493. With an introduction, etc., by Singer, Charles. Part 1, p. 97.

25. Benedicti, A. Opera. Venice, I533, p. 463.

Estienne, C., and Rivière, E. De Dissectione Partium Corporis humani. Paris, 1545, p. 347 . 